\title{
Book Review: Mohammed Hanif's Red Birds: a Wildly Satiric, Piercingly Real and Darkly Humorous Narrative
}

\author{
Book Name: Red Birds \\ Author: Mohammed Hanif \\ Genre: Fiction \\ Publisher: Bloomsbury \\ Year of Publication: 2018 \\ ISBN: HB: 978-1-4088-9718-8
}

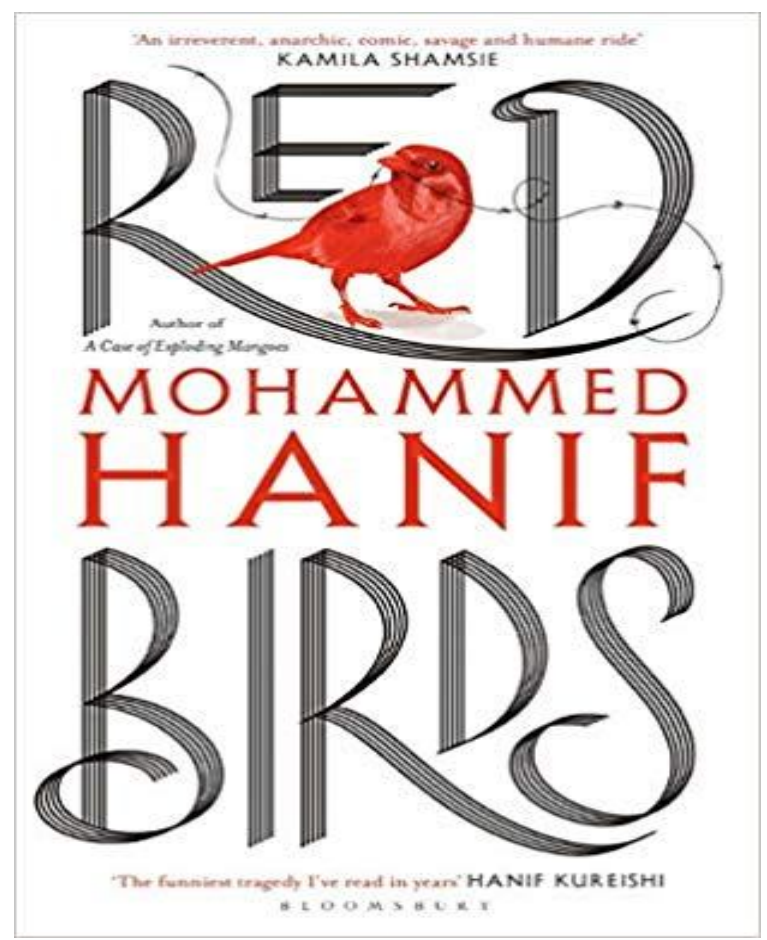

Reviewed by

Sukanya Saha

Assistant Professor, Department of English, SRM Institute of Science and Technology SRM Nagar, Kattankulathur. Tamilnadu.Email: sukanyap@srmist.edu.in

Red Birds' is stylistically and thematically compelling narrative, weaving its tapestry with multiple perspectives, giving haunting insights laced with sarcasm. It is a remarkable feat of verbal audacity, wise, searing, psychologically intimate and fast paced examination of lives. Hanif admits that the book is not autobiographical in anyway, because his personal life is 'fairly dull and predictable in a middle class kind of way'.

(c) AesthetixMS 2019. This Open Access article is published under a Creative Commons Attribution Non-Commercial 4.0 International License (http://creativecommons.org/licenses/by-nc/4.o/), which permits non-commercial re-use, distribution, and reproduction in any medium, provided the original work is properly cited. For citation use the DOI. For commercial re-use, please contact editor@rupkatha.com. 
The ground reality of war could be fiercely intimidating, 'like all the dead from their bombing, pulling themselves out of their graves and trying to tell the stories of their abruptly ended lives.' (192), but Hanif's approach is a distraction, taking narrative to a plane where ascertaining the core is wading through or grappling with the absurd truths and irreverent satires. This process grows deeply engrossing with three POVs digressing from the sordid, disturbing, or ghastly facets of war with open jibes. For Hanif, these are 'tears of blood' and proclaims himself in 'every character, every place, every emotion, every grain of sand, every little joke', yet, dextrously detaching his being from these daring revelations. Disrupting the traditional narratives about grief, deaths, violence, or politics in structure and theme, Hanif shows immense perspicacity in keeping the novel lively and darkly incisive. Its architecture is that of psychological probing, assessing the pitfalls of a prolonged war. However, he seems to dig out the fallacy in human conduct too.

When my folks don't have a real explanation, they blame it on war. As if before the war we were all a brotherhood and didn't throw our trash into our neighbour's yard. As if war gave us bad breath and crude manners. (83)

There seems to be no specific inspirational source which fuels Hanif's acrid and bracing narration. It is a perpetual meditation on cumulative griefs of a set of characters who survive entangled in poignant emotional perplexities: Mother Dear, whose firstborn is missing and despite being wary of slim chances, aspires to bring him back; Momo, apart from his business plans, harbours finding his missing brother as a mission in mind; Father Dear, a passive spectator, scrupulously maintains records in vain, which neither anyone needs nor pays heed; Ellie, in whose brain jostle the thoughts of personal and professional failures; Lady Flowerbody, whose research ventures about 'young Muslim minds', are destined to yield futile inferences; the Doctor, who survives despite meagre supplies, with his bent for novelty. There is of course, a 'philosopher' Mutt, having the worst day of his life already, repeatedly claims of being gifted with an unusual sense of smell and intellectuality superior to humans.

In spite of composing a righteously outraged narrative and suffusing it with existential implications, Hanif does not invite symbolically or allegorically oriented interpretations. His purpose in mooring to realism is to upraise the novel's readability quotient highlighting aftermaths of living through wars and how people made fortunes from these wars. He confesses that his report coverage of war torn families in Baluchistan and missing people there, has seeped into Red Birds in the form of Ali's disappearance. The stirrings consequent to it do not lead to tumultuous eruptions, yet, cast a seething sensation which nurtures apprehensions about him being dead or physically mutilated. Hanif, however, did not keep Ali's disappearance as mystery and closes the novel adding to miseries of a grief stricken, hallucinating mother and of a brother who has to live with the guilt of not being able to save him.

Ellie, Momo and Mutt's streams of consciousness are steeped in empathy, cynicism and sporadic humour. The novel's setting, an unnamed refugee camp and a 'Hangar' amidst a never ending desert is a half-forgotten, desolate place in which the world outside is too busy to take interest and which thrives on supplies from post war reliefs and thievery, "These people; my people, they are nothing but thieves with tears' (20). Presenting a Mutt with intelligentsia does not startle. The author has to raise his game and despite bizarreness, these augment the sarcasm. Mutt's assiduous philosophising are mockery of human's inability to understand basic codes of living, 'When they want to fight evil they become evil' (100), 'death is a bit more irksome than living with the memory of those who have already left' (101), or, '...there are lessons that young Muslim minds can learn. And the first one is that depression and sexual depravity are indeed first 
cousins' (136.) There are several such adages which would fill an entire thesis on Mutt's haranguing. Mutt's perceptions are guided by its unique sense of smell with which it forms strong impressions about human intent or character.

The house always smells of tricks. Everybody doing something for the other because it for their own good. The air in this house is like a thick onion soup'. (134)...Of course, the boy pretends that his life is all about business and Bro Ali, but go on have a sniff, he smells of lust on the verge of self-combustion. Delusions smell of synthetic vinegar. (135)... He [Momo] has left me here with a smell of sadness so overwhelming that I could be in a salt mine.(136)...I am lost in these smells...Where is your smell? What kind of person doesn't have a smell? I think I know someone else who doesn't have a smell' (208).

The 'fried brain' has supposedly turned Mutt into a philosopher and imparted it insights and farsightedness alien to humans, 'This is what life is all about; you live and learn to manage your pain' (135). Hanif seems to imply that one has to transcend the confines of saneness to grasp 'Something has happened to everyone and if it hasn't happened yet, it will happen. Only a matter of time'.

Momo and Ali, the 'young Muslim minds', are adventurous, keen on exploring. Unfortunately, they are born and raised in non-normal circumstances, amongst constant bombings, devastations, deaths and disappearances. Ali is good at mechanics and Momo dwells in money-making schemes. Momo, the capitalist, whose business ventures never materialise, strikes as smart, entrepreneurial, and compassionate youth. His visualization of Ali's ghost and disbelief of finding his brother dead is nerve-wracking.

I can tell that he is alive (275)...my palm on Bro Ali's heart. It's still. I wait and wait but there is no beat' (277) 'You have to close my eyes,' he says. I look into his eyes, they are wide open. I can see two Momos reflected in them. 'Do it gently', he says. I tighten my grip around his waist. He doesn't judo-tackle me. (278)

The profundity in his monologues is one of the highlights of this book, which hold forth the crude and unpalatable realism. He is wary of the plights of 'My land my people' (146) and broods over the irony in veracities which lead to this abjectness.

They bomb us because they assume we are related to bad Arabs. We steal from them because that's all we can do. They take our boys because they think that's all we have. And to lure the boys they sent out their tallest soldiers, their shiniest vehicles (65)...First they bomb us from the skies, then they work hard to cure our stress (67)... I try to imagine a world where people read a book by a writer about a place where the writer has never been and then decide to go there to study young minds. We live in that world. Not much different from the white men (and women, but mostly men) who flew halfway around the world to bomb us because they believe even if we are not bad Arabs we must be up to something. (70)

Momo's is that anguishing plight which their generation is subjected to deal with denied of alternatives. They are often orphaned, their schools and homes are devastated, playmates or siblings go missing forever untraceably. About his brother's disappearances he churned up speculations which in turn become increasingly throbbing to ponder over.

I have to admit that Bro Ali going away like this was a blow we are still recovering from. I was forced to take on the responsibility of running the household; drying Mother Dear's tears, pressing Father Dear's pants. I am not going to school either. And if I am not gonna 
go to school, then school is gonna remain shut. Buffaloes needed their shelter back, now they have it. (18)... There were boys before him who went and never came back'. (72)

The resentment and cynicism surfaces in his attitude towards Lady Flowerbody's research.

She is here to research my trauma. I intend to take her into the very heart of trauma (65)...It's bit sickening to be described as evil. We are entrepreneurs, not evil. Why is she investigating this? Is she interested in our feelings or their feelings? (148).

Ellie has been meted out to the similar plight except the sources of his are career and marital discord. War is his escape from wife. The vainness in exhibiting remarkable feat of past bombing missions irks him, 'I feel that after all those near-death experiences, after all the sacrifices I have made for the country, I am being treated like an unwanted hitchhiker' (89). Ellie is the agent of those perpetrators who seem to have lost interest in bombing and supplying aids. He mocks at the refugee camp,

I...try to read writing on the gate: USAID FUGEE CAMP. The RE seems to have dislodged itself out of embarrassment...NO LITTERING signs over piles of litter...What was I thinking? What was Colonel Slatter thinking? He came to bomb this place because he thought it was an existential threat to our great nation. (92-3)

Ellie's notions about the essentialities of war leads one to contemplate over the pinnacles Hanif's sarcasm has reached, where he dares to make Ellie justify the dastardliness of wars,

If I didn't bomb some place, how would she save that place? If I didn't rain fire from the skies, who would need her to douse that fire on the ground? Why would you need somebody to throw blankets on burning babies if there were no burning babies? If I didn't take out homes who would provide shelter? If I didn't take out homes who would need shelter? If I didn't obliterate cities, how would you get to set up refugee camps? Where would all the world's empathy go? Who would host exhibitions in the picture galleries of Berlin, who would have fund raising balls in Lindon? Where would all the students on their gap years go? ...You don't hold candlelight vigils for those dying of old age and neglect. You need fireworks to ignite human imagination.' (201)

The overwhelming presence of the titular 'Red Birds' in Mutt's hallucinations evoke an uncanny sensation of drowning in a fathomless pit of despondency. They are stubbornly still, neither fluttering their wings nor attempting to fly, signifying the doom of that godforsaken land, haunted with memories of the dead that refuse to wither and resurface with every effort at forgetting them. They are images painted with blood, perhaps are from other-world, lurking in this space as silent spectators. These reappear amidst the puffs of red dust in the Hangar while Mother Dear, Momo and Mutt sight them simultaneously during their rescue mission for Ali. Ghosts of the dead, Cath, Colonel Slatter, and Ali suffuse the air with this unnerving dust.

The book jacket of the novel puts it succinctly, 'Written with Mohammed Hanif's trademark wit and deadpan irony, Red Birds is a savage, irreverent satire telling important truths about the absurdity of war and impossibility of peace.' Hanif's sarcasm doesn't spare even the God, 'God is not done with us yet, and He created this world but He didn't promise us discounts on tinned beef and fresh vegetables-or the safety of our siblings...(245), yet he concluded the novel with a series of attributes to that supreme power who reigns amidst atrocities, in Mother Dear's wailings. This novel is for those who like audacious bravado yet appreciate tender empathy. 